\title{
Feedback Regulation of 3-Hydroxy-3-Methylglutaryl Coenzyme A Reductase in Livers of Mice Treated with Mevinolin, a Competitive Inhibitor of the Reductase
}

\author{
Toru Kita, Michael S. Brown, and Joseph L. Goldstein, Departments of \\ Molecular Genetics and Internal Medicine, University of \\ Texas Health Science Center at Dallas, Texas 752.35
}

\begin{abstract}
A B S T R A C T Compactin (ML-236B) and the related compound, mevinolin, are competitive inhibitors of 3-hydroxy-3-methylglutaryl coenzyme A reductase (HMG CoA reductase), the rate-controlling enzyme in cholesterol synthesis. Previous studies have shown that administration of compactin to cultured cells elicits a compensatory increase in the amount of HMG CoA reductase in the cells. A similar increase in HMG CoA reductase has been reported in livers of rats and mice that have been treated with compactin. In this study, we explore the mechanism for the mevinolinmediated increase in hepatic HMG CoA reductase in mice that have been fed a control diet and a $2 \%$ cholesterol diet. Administration of mevinolin to mice on a control diet produced a 6 - to 10 -fold increase in the amount of HMG CoA reductase in liver microsomes. When mice were fed the cholesterol-enriched diet, cholesterol accumulated in the liver and HMG CoA reductase declined by $90 \%$. The administration of mevinolin to cholesterol-fed mice produced a three to eightfold increase in HMG CoA reductase. Despite the abundant amount of cholesterol that was already present in the livers of the mevinolin-treated, cholesterol-fed animals, their elevated HMG CoA reductase could be rapidly suppressed by the subcutaneous injection of small amounts of mevalonate, the product of HMG CoA reductase. These data are compatible with the existence in mouse liver of a multivalent feedback regulatory mechanism for HMG CoA reductase in which suppression of the enzyme requires both a sterol and a nonsterol substance derived from mevalonate. By blocking mevalonate synthesis, mevinolin activates this regulatory mechanism, and this in turn causes an increase in hepatic HMG CoA reductase. The ability to suppress the elevated HMG
\end{abstract}

Dr. Toru Kita is the recipient of a travel grant from the Japan Research Foundation for Clinical Pharmacology.

Received for publication 29 May 1980.
CoA reductase with mevalonate may prove useful in potentiating the effectiveness of mevinolin as a hypocholesterolemic agent.

\section{INTRODUCTION}

The discovery by Endo et al. (1) of compactin (ML 236-B), a competitive inhibitor of 3-hydroxy-3-methylglutaryl coenzyme A reductase (HMG CoA reductase), ${ }^{1}$ the rate-controlling enzyme in cholesterol synthesis, has important implications for the therapy of hypercholesterolemia in man (2). Compactin, which was originally isolated from Penicillium brevicompactum (3), is a potent inhibitor of cholesterol synthesis in intact animals $(1,4)$ and in cultured cells $(5-7)$. Recently, a related fungal metabolite, called monacolin $\mathrm{K}$ (8) or mevinolin (9), has been isolated from different fungal strains. Alberts et al. (9) demonstrated that the structure of mevinolin resembles that of compactin except for the presence of one additional methyl group. These workers also showed that mevinolin is even more potent than compactin in its ability to inhibit HMG CoA reductase activity.

An unexpected action of compactin, which was first noted in cultured human fibroblasts, is its ability to cause the accumulation of large amounts of HMG CoA reductase enzyme in the cell (5). Accumulation of the enzyme occurs in response to a regulatory mechanism that is triggered when compactin inhibits HMG CoA reductase and thereby deprives the cells of mevalonate, the product of the enzyme. The induced HMG CoA reductase is not active in the cell because it is inhibited by compactin. However, its activity can be measured in cell-free extracts in which the compactin-mediated inhibition is overcome by dilution (5). The high levels of HMG CoA reductase are suppressed

\footnotetext{
${ }^{1}$ Abbreviation used in this paper: HMG CoA reductase, 3-hydroxy-3-methylglutaryl coenzyme A reductase.
} 
partially when the cells are given exogenous cholesterol, the major end product of mevalonate metabolism. Full suppression of HMG CoA reductase occurs only when the cells are given small amounts of mevalonate in addition to exogenous cholesterol $(5,10)$. These findings have led to the hypothesis that HMG CoA reductase is normally regulated in cultured cells by a multivalent process in which full suppression of the enzyme requires both cholesterol and one or more nonsterol products derived from mevalonate $(5,10)$. By inhibiting mevalonate synthesis, compactin activates this regulatory mechanism and causes HMG CoA reductase levels to rise.

Subsequent studies have demonstrated an increase in HMG CoA reductase in the livers of mice and rats that have been treated with oral compactin (11). This increase in HMG CoA reductase is of practical concern because it creates a resistance to the effectiveness of compactin in inhibiting cholesterol synthesis (11). Inasmuch as compactin is a competitive inhibitor of the enzyme, a given level of compactin inhibits the enzyme by a fixed percentage. As the amount of HMG CoA reductase increases, an increasing percentage of inhibition is required to reduce cholesterol synthesis to a given absolute value (5-7).

It is important to determine whether the mechanism for the compactin-mediated increase in HMG CoA reductase in rodent liver is similar to that proposed for cultured cells. If such a multivalent feedback regulatory mechanism were operative in the liver, then compactin (or the related compound mevinolin) should produce an increase in hepatic HMG CoA reductase even in animals that have been fed cholesterol and have accumulated large amounts of cholesterol in the liver. The increase should be suppressed by the administration of mevalonate, which should exert an additional effect even in the presence of maximally effective levels of cholesterol. In the current studies, we have administered mevinolin to mice to test the above hypothesis. The results are consistent with the existence of a multivalent feedback regulatory mechanism in mouse liver that is responsive to the combination of exogenous cholesterol and mevalonate.

\section{METHODS}

Materials. D,L-3-Hydroxy-3-methyl-[3-14C]glutaric acid $(58.6 \mathrm{mCi} / \mathrm{mmol})$ was purchased from New England Nuclear Corp., Boston, Mass. [3R,4R-4- $\left.{ }^{3} \mathrm{H}+3 S, 4 S-4-{ }^{3} \mathrm{H}\right]$ mevalonic acid lactone $(1.8 \mathrm{Ci} / \mathrm{mmol})$ was obtained from Amersham Corp., Arlington Heights, Ill. Escherichia coli alkaline phosphatase suspended in $2.6 \mathrm{M}$ ammonium sulfate (40$52 \mathrm{U} / \mathrm{mg}$ protein) was obtained from Worthington Biochemicals, Inc., Freehold, N.J. (catalog no. LS00-06124). Just before use, the enzyme suspension was centrifuged, and the precipitated enzyme was dissolved in buffer $A(20 \mathrm{mM}$ imidazole-chloride [pH 7.4] and $5 \mathrm{mM}$ dithiothreitol) as previously described (12). Cholesterol was purchased from
ICN Pharmaceuticals Inc., Irvine, Calif. Wayne Laboratory Animal Diet (formula chow) was obtained from Allied Mills, Inc., Chicago, Ill. D,L-Mevalonic acid lactone was obtained from Sigma Chemical Co., St. Louis, Mo. Mevinolin (L-154, 803-00G 17) was kindly provided by Alfred W. Alberts of Merck Sharp \& Dohme Research Laboratories, Rahway, N. J. Other chemicals were obtained from sources as previously reported $(5,12)$.

Animals, diets, and drug treatments. Male Swiss-Webster mice, weighing between 25 and $30 \mathrm{~g}$, were obtained from Simonson Laboratories, San Francisco, Calif., and housed in gang cages. The animals were exposed to a light-dark cycle consisting of $12 \mathrm{~h}$ of light ( 6 a.m. to 6 p.m.) and $12 \mathrm{~h}$ of darkness (6 p.m. to 6 a.m.) for $1-2$ wk before use and during the experimental period.

To prepare the $2 \%$ cholesterol diet, $20 \mathrm{~g}$ of cholesterol was dissolved in $400 \mathrm{ml}$ of warm $\left(55^{\circ} \mathrm{C}\right)$ ethanol, and the solution was mixed with $1 \mathrm{~kg}$ of powdered formula chow, after which the ethanol was removed by evaporation. The control diet consisted of powdered formula chow.

For administration to animals, $90 \mathrm{mg}$ of mevinolin in the lactone form was dissolved in $1.8 \mathrm{ml}$ of warm $\left(55^{\circ} \mathrm{C}\right)$ ethanol, after which $0.9 \mathrm{ml}$ of $0.6 \mathrm{~N} \mathrm{NaOH}$ and $18 \mathrm{ml}$ of water were added. The solution was incubated at room temperature for about $30 \mathrm{~min}$ to complete the conversion of mevinolin to the sodium salt. The final mevinolin solution $(4 \mathrm{mg} / \mathrm{ml})$ was adjusted to $\mathrm{pH} 8.0$ with $\mathrm{HCl}$ and the volume was brought to $22.5 \mathrm{ml}$. This mevinolin solution was stored in multiple aliquots at $-20^{\circ} \mathrm{C}$ until use. Control animals received a solution prepared in the same way except that mevinolin was omitted (solution A). Mevalonolactone $(100 \mathrm{mg} / \mathrm{ml}$ ) was dissolved in $10 \mathrm{mM}$ potassium phosphate ( $\mathrm{pH} 4.5)$ and stored in multiple aliquots at $-20^{\circ}$ until use.

Preparation of liver microsomes. Mice were killed by decapitation between 1 and 2 p.m., the livers were immediately removed, and equal pieces of livers from three animals $(\sim 0.5 \mathrm{~g} /$ liver) were pooled. All subsequent operations were carried out at $4^{\circ} \mathrm{C}$ unless otherwise indicated. Each group of pooled livers $(1.5 \mathrm{~g})$ was homogenized in $6 \mathrm{ml}$ of ice-cold solution containing $0.3 \mathrm{M}$ sucrose, $10 \mathrm{mM} \beta$-mercaptoethanol, and $10 \mathrm{mM}$ sodium EDTA ( $\mathrm{pH} 7.4$ ). The livers were homogenized with 10 strokes of a loose Dounce pestle followed by 5 strokes of a tight pestle. Aliquots were removed for measurement of free and esterified cholesterol content. Each homogenate was then centrifuged for $15 \mathrm{~min}$ at $12,000 \mathrm{~g}$, and the supernatant fraction was again centrifuged for $15 \mathrm{~min}$ at $12,000 \mathrm{~g}$. The resulting supernate was centrifuged for $60 \mathrm{~min}$ at $100,000 \mathrm{~g}$. Each pellet was resuspended in $4 \mathrm{ml}$ of solution containing $0.3 \mathrm{M}$ sucrose and $10 \mathrm{mM} \beta$-mercaptoethanol, and this suspension was again centrifuged for $60 \mathrm{~min}$ at $100,000 \mathrm{~g}$. Unless otherwise indicated, the resulting microsomal pellets were frozen immediately in liquid nitrogen and were stored at $-80^{\circ} \mathrm{C}$. Before assay of HMG-CoA reductase activity, each pellet (3.4-18 $\mathrm{mg}$ of protein) was resuspended in 1-6 ml of buffer $A(20 \mathrm{mM}$ imidazolechloride [ $\mathrm{pH}$ 7.4] and $5 \mathrm{mM}$ dithiothreitol).

Standard assay of microsomal HMG CoA reductase. The standard assay for HMG CoA reductase activity consisted of two sequential steps as previously described (12): $(a)$ a prior incubation period during which microsomes were incubated in the presence of $E$. coli alkaline phosphatase, and $(b)$ a subsequent incubation period during which the activity of HMG CoA reductase was measured. Unless otherwise stated, the prior incubation mixture contained the following concentrations of components in a volume of $90 \mu \mathrm{l}: 20 \mathrm{mM}$ imidazole-chloride ( $\mathrm{pH} 7.4$ ), $5 \mathrm{mM}$ dithiothreitol, 0.74-150 $\mu \mathrm{g}$ of microsomal protein, and $5 \mathrm{U}$ of $E$. coli alkaline phosphatase. The tubes were incubated at $37^{\circ} \mathrm{C}$ for $60 \mathrm{~min}$, after 
which $100 \mu$ l of solution containing $0.2 \mathrm{M}$ potassium phosphate (pH 7.4), $40 \mathrm{mM}$ D-glucose 6-phosphate, $12 \mathrm{mM}$ dithiothreitol, $4 \mathrm{mM}$ NADPH, and $10 \mathrm{mM}$ sodium EDTA was added. The HMG CoA reductase assay was then initiated with the $10-\mu l$ addition of $\mathrm{D}, \mathrm{L}-\left[3-{ }^{14} \mathrm{C}\right] \mathrm{HMG} \mathrm{CoA}(13,500 \mathrm{cpm} / \mathrm{nmol})$ to a final concentration of $87 \mu \mathrm{M}$ (final assay volume, $200 \mu \mathrm{l}$ ). After incubation for $60 \mathrm{~min}$ at $37^{\circ} \mathrm{C}$, the $\left[{ }^{14} \mathrm{C}\right]$ mevalonate formed was converted into the lactone, isolated by thin-layer chromatography, and counted using an internal standard of $\left[{ }^{3} \mathrm{H}\right]-$ mevalonate to correct for incomplete recovery (12). HMG CoA reductase activity is expressed as the picomoles of $\left[{ }^{14} \mathrm{C}\right]$ mevalonate formed per minute per milligram of microsomal protein. Unless otherwise stated in the legends, each microsomal extract was assayed with three or four different amounts of protein to assure linearity of $\left[{ }^{14} \mathrm{C}\right] \mathrm{mevalonate}$ formation with protein concentrations. The values in the Figures and Tables represent the mean of these assays.

Other assays. The protein content of membranes was determined by the method of Lowry et al. (13), with bovine serum albumin as a standard. The content of free and esterified cholesterol in whole homogenates of liver was measured by gas-liquid chromatography as previously described (14).

\section{RESULTS}

Subcutaneous administration of mevinolin to mice at a dose of $33-40 \mathrm{mg} / \mathrm{kg}$ body wt every $12 \mathrm{~h}$ produced an increase in hepatic HMG CoA reductase activity that remained high throughout the 12-h interval between doses. $28 \mathrm{~h}$ after the initiation of this treatment schedule,

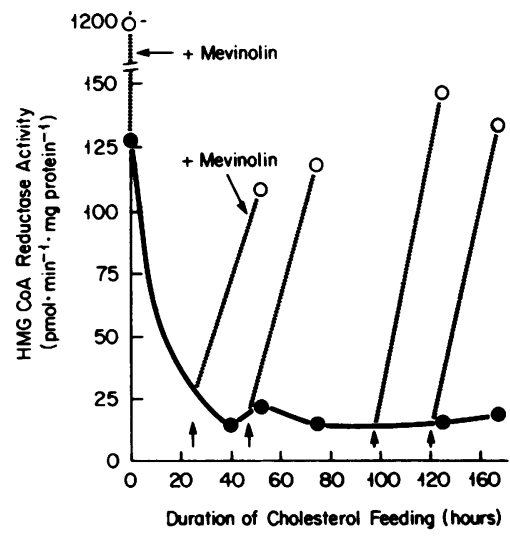

FIGURE 1 Mevinolin-mediated enhancement of HMG CoA reductase activity in the livers of cholesterol-fed mice. Groups of mice (three mice per group) were fed a $2 \%$ cholesterol diet for the indicated time. The onset of the diet was staggered in such a way that all animals could be killed at the same time after having consumed the diet for variable periods as indicated. At the designated time after beginning the cholesterol diet (arrow), groups of animals were injected subcutaneously with $1 \mathrm{mg}$ of mevinolin (O). The injections were repeated twice at 12-h intervals (total of three injections). Control groups of animals were injected subcutaneously with solution A (three injections at $12-\mathrm{h}$ intervals $(0)$. All the animals were killed on the same day at 1 p.m., $4 \mathrm{~h}$ after the last injection of mevinolin. The livers from the three mice in each group were pooled for homogenization. Microsomes were prepared, treated with alkaline phosphatase, and assayed for HMG CoA reductase activity as described under Methods. the HMG CoA reductase activity in control mice was elevated by $>10$-fold (open circle at zero time in Fig. 1). When the mice were fed a diet containing $2 \%$ cholesterol, hepatic HMG CoA reductase activity declined by $>90 \%$. The reduction was maximal at $40 \mathrm{~h}$ and was sustained throughout $170 \mathrm{~h}$ of cholesterol feeding. Administration of mevinolin at any time during this cholesterol feeding period led to a large increase in HMG CoA reductase activity that was manifest $28 \mathrm{~h}$ later (open circles, dashed lines in Fig. 1). In the cholesterol-fed mice, mevinolin raised the HMG CoA reductase activity from an average of 15 to $\sim 125 \mathrm{pmol} /$ min per mg protein, an increase of eightfold.

Despite the large differences in the absolute levels of HMG CoA reductase activity among the various treatment groups in Fig. 1, a range of protein concentrations could be found in each case in which the HMG CoA reductase assay was linear with increasing amounts of added microsomes (Fig. 2). Under these conditions, the assay was also linear with time up to at least $90 \mathrm{~min}$ (data not shown). The enzyme concentration curves in Fig. 2 also illustrate the increase in HMG CoA reductase activity produced by mevinolin in control animals (Fig. 2A) and in animals fed a $2 \%$ cholesterol $\operatorname{diet}$ (Fig. 2B).

Hepatic HMG CoA reductase exists in two interconvertible forms $(12,15-17)$. In its phosphorylated form, the enzyme is inactive, whereas in the nonphosphorylated form it is active (15-17). Homogeniza-

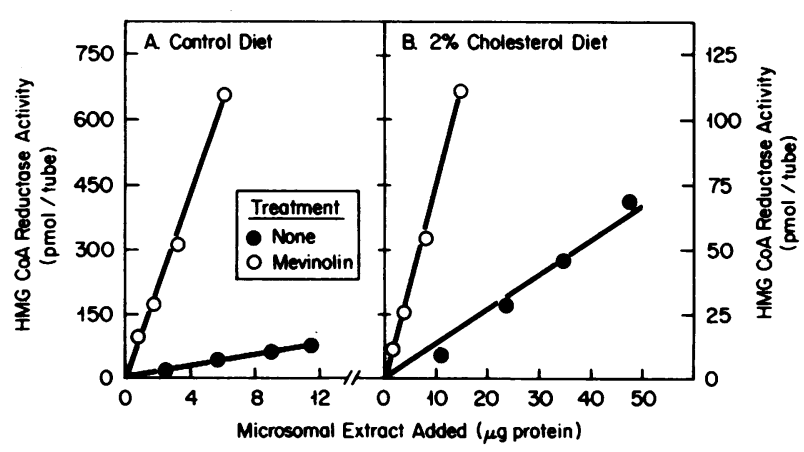

Figure 2 Activity of HMG CoA reductase in liver microsomes from control (A) and cholesterol-fed (B) mice treated with $(O)$ and without $(O)$ mevinolin. Six mice were fed either a control diet (A) or a $2 \%$ cholesterol diet for $8 \mathrm{~d}$ (B). $7 \mathrm{~d}$ after beginning the diet, groups of three control mice and three cholesterol-fed mice were injected subcutaneously with 0.25 $\mathrm{ml}$ of solution A with (O) or without (O) $1 \mathrm{mg}$ of mevinolin. The injections were repeated twice at 12 -h intervals (total of three injections). All mice were killed at 1 p.m., $4 \mathrm{~h}$ after the last injection. The livers from the three mice in each treatment group were pooled for homogenization. Microsomes were prepared and treated with alkaline phosphatase. Varying amounts of microsomal protein were then incubated under standard assay conditions for $60 \mathrm{~min}$ at $37^{\circ} \mathrm{C}$, and the amount of $\left[{ }^{14} \mathrm{C}\right]$ mevalonate formed was determined as described under Methods. Each value represents the average of duplicate assays. 
tion of the liver in the presence of sodium fluoride prevents the dephosphorylation that normally occurs when the liver is homogenized (15) and is thus felt to preserve the relative proportions of active and inactive enzymes that were present originally in the tissue $(12,15)$. Treatment of the isolated microsomes with $E$. coli alkaline phosphatase removes the phosphate group from the enzyme and permits an estimate of the total amount of enzyme (active plus inactive) in the tissue (15). In the preceding experiments, the homogenates were prepared in the absence of fluoride, and the microsomes were treated with alkaline phosphatase before assay to measure the total amount of hepatic HMG CoA reductase. To estimate the proportion of reductase that was in the active form, we performed an experiment in which the animals were placed on a control or $2 \%$ cholesterol diet and then treated with or without mevinolin (Table I). Livers from animals in each of the four groups were then homogenized in the absence or presence of sodium fluoride, and portions of the microsomes were assayed either without prior incubation or after prior incubation with alkaline phosphatase to activate the phosphory- lated enzyme. In the control animals, the activity of HMG CoA reductase in the fluoride-treated microsomes was low and was stimulated sevenfold by treatment with alkaline phosphatase. This degree of enhancement is similar to the one previously observed in rat liver $(12,15)$. When the animals were treated with mevinolin, the total HMG CoA reductase activity rose by $\sim 6.5$-fold, and the relative stimulation by alkaline phosphatase in the fluoride-treated microsomes did not change significantly. When the mice were fed cholesterol, the total reductase activity declined by $\sim 85 \%$. The fluoride-treated enzyme was stimulated $\sim$ twofold by alkaline phosphatase treatment, suggesting that a proportion of enzyme was still in the inactive form in the tissue. Administration of mevinolin to the cholesterol-fed mice increased the total HMG CoA reductase activity threefold, from 18 to $51 \mathrm{pmol} /$ min per mg protein. Again, the degree of stimulation of the fluoride-treated microsomes by alkaline phosphatase was not changed by mevinolin.

Table I also shows that the cholesterol content of the liver rose normally in the cholesterol-fed animals that were treated with mevinolin. Thus, in the choles-

TABLE I

HMG CoA Reductase Activity and Cholesterol Content in Livers of Mice Fed Cholesterol and Treated with and without Mevinolin

\begin{tabular}{|c|c|c|c|c|c|c|c|}
\hline \multirow{2}{*}{\multicolumn{2}{|c|}{ Treatment of mice }} & \multirow{3}{*}{$\begin{array}{c}\text { Preparation } \\
\text { of } \\
\text { microsomes }\end{array}$} & \multicolumn{2}{|c|}{ HMG CoA reductase activity } & \multirow{2}{*}{\multicolumn{3}{|c|}{ Cholesterol content }} \\
\hline & & & & & & & \\
\hline \multirow[t]{2}{*}{ Diet } & Mevinolin & & phosphatase & phosphatase & Total & Free & Esterified \\
\hline & & & \multicolumn{2}{|c|}{ pmol/min/mg protein } & \multicolumn{3}{|c|}{ wh sterol/mg protein } \\
\hline \multirow[t]{2}{*}{ Control } & $\mathbf{0}$ & $+\mathrm{NaF}$ & 13 & 94 & 14 & 13 & 1.1 \\
\hline & & $-\mathrm{NaF}$ & 65 & 87 & 14 & 13 & 1.1 \\
\hline \multirow[t]{2}{*}{ Control } & + & $+\mathrm{NaF}$ & 63 & 410 & 12 & 10 & 1.7 \\
\hline & & $-\mathrm{NaF}$ & 390 & 579 & 12 & 11 & 1.6 \\
\hline \multirow[t]{2}{*}{$2 \%$ Cholesterol } & 0 & $+\mathrm{NaF}$ & 7.2 & 12 & 60 & 17 & 43 \\
\hline & & $-\mathrm{NaF}$ & 15 & 18 & 60 & 18 & 42 \\
\hline \multirow[t]{2}{*}{ 2\% Cholesterol } & + & $+\mathrm{NaF}$ & 20 & 60 & 74 & 19 & 55 \\
\hline & & $-\mathrm{NaF}$ & 31 & 51 & 72 & 19 & 53 \\
\hline
\end{tabular}

Six mice were fed either a control diet or a $2 \%$ cholesterol diet for $76 \mathrm{~h}$ as indicated. $48 \mathrm{~h}$ after beginning the diet, groups of three control mice and three cholesterol-fed mice were injected subcutaneously with $0.25 \mathrm{ml}$ of solution $\mathrm{A}$ with or without $1 \mathrm{mg}$ of mevinolin as indicated. The injections were repeated twice at 12 -h intervals (total of three injections). All mice were killed at 1 p.m., $4 \mathrm{~h}$ after the last injection. The livers from the mice in each group were pooled. Equal portions from each pool of livers were homogenized in solution containing $0.3 \mathrm{M}$ sucrose, $10 \mathrm{mM} \beta$-mercaptoethanol, $10 \mathrm{mM}$ sodium EDTA ( $\mathrm{pH} 7$ ), and either $50 \mathrm{mM}$ sodium fluoride (+ $\mathrm{NaF}$ ) or 50 mM sodium cholride $(-\mathrm{NaF})$ as indicated. Aliquots of the homogenates were removed for measurement of cholesterol content as described under Methods. Microsomes were prepared from the homogenates as described under Methods except that each $100,000 \mathrm{~g}$ pellet was resuspended in $4 \mathrm{ml}$ of solution containing $0.3 \mathrm{M}$ sucrose, $10 \mathrm{mM} \beta$-mercaptoethanol, and either $50 \mathrm{mM}$ sodium fluoride $(+\mathrm{NaF})$ or $50 \mathrm{mM}$ sodium chloride $(-\mathrm{NaF})$ as indicated. Microsomes were preincubated as described under Methods except that the mixture was incubated for 60 min either in the absence of alkaline phosphatase at $4^{\circ} \mathrm{C}\left(-\right.$ alkaline phosphatase) or in the presence of $5 \mathrm{U}$ of alkaline phosphatase at $37^{\circ} \mathrm{C}(+$ alkaline phosphatase) as indicated. HMG CoA reductase activity was then assayed by the standard method. Each value represents the average of duplicate assays of microsomes from pooled livers from three similarly treated animals. 
terol-fed animals, mevinolin produced an increase in HMG CoA reductase in the face of a marked elevation in hepatic cholesterol content.

Edwards et al. (18) have shown that administration of large amounts of mevalonate orally to rats produces a prompt decline in hepatic HMG CoA reductase activity, apparently because the mevalonate is converted to sterols and perhaps other products that suppress the activity of the enzyme. In mice, the elevated HMG CoA reductase activity that was elicited by mevinolin was also rapidly suppressed when the animals were given mevalonate subcutaneously (Fig. 3). In mice on a control diet plus mevinolin (Fig. 3A), the activity of HMG CoA reductase was high and was suppressed by $\sim 90 \%$ within $2 \mathrm{~h}$ after the subcutaneous injection of $10 \mathrm{mg}$ of mevalonate in the lactone form. When the animals had been fed a high cholesterol diet, and HMG CoA reductase activity had been elevated by mevinolin (Fig. 3B), the administration of mevalonolactone also produced a rapid decline in hepatic HMG CoA reductase (Fig. 3B).

The dose-response curve for mevalonate was different in the control and cholesterol-fed animals treated with mevinolin (Fig. 4). In the mevinolin-treated animals on a control diet, the administration of small amounts of mevalonolactone ( $<1 \mathrm{mg} /$ mouse) led to a paradoxical twofold increase in HMG CoA reductase activity as measured $3 \mathrm{~h}$ later. At doses of mevalonolactone $>1 \mathrm{mg}$, the activity was suppressed. A similar

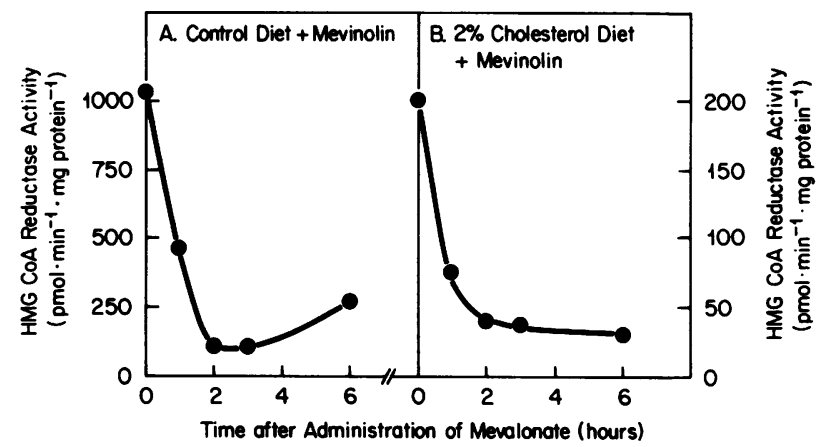

FIGURE 3 Suppression by mevalonate of the elevated hepatic HMG CoA reductase activity in mevinolin-treated control and cholesterol-fed mice. Five groups of mice (three mice per group) were fed either a control $\operatorname{diet}(\mathrm{A})$ or a $2 \%$ cholesterol diet (B) for $53 \mathrm{~h} .23 \mathrm{~h}$ after beginning the diet, the mice in both diet groups were injected subcutaneously with $1 \mathrm{mg}$ of mevinolin. The injections were repeated twice at 12 -h intervals (total of three injections). At the indicated time before killing, the animals in each group received one subcutaneous injection of $10 \mathrm{mg}$ of mevalonolactone. All mice were killed at 2 p.m., $6 \mathrm{~h}$ after the last dose of mevinolin. The livers from the three mice in each group were pooled for homogenization. Microsomes were treated with alkaline phosphatase and assayed for HMG CoA reductase activity as described under Methods.

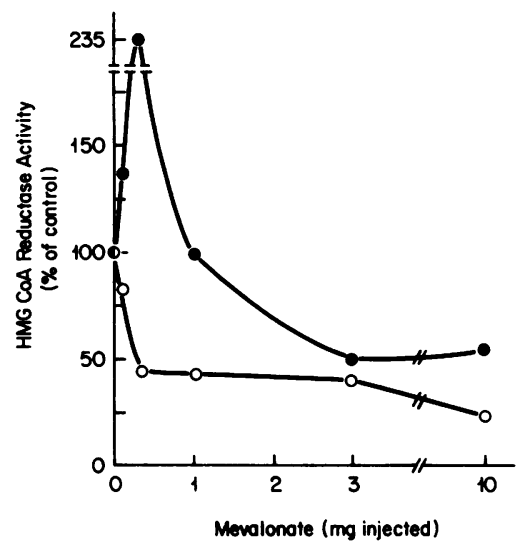

Figure 4 Suppression of hepatic HMG CoA reductase activity in mevinolin-treated control and cholesterol-fed mice as a function of the amount of administered mevalonate. Groups of mice (three mice per group) were fed a control $\operatorname{diet}(O)$ or a $2 \%$ cholesterol diet $(O)$ for $54 \mathrm{~h} .23 \mathrm{~h}$ after beginning the diets, mice in both diet groups were injected subcutaneously with $1 \mathrm{mg}$ of mevinolin. The injections were repeated twice at 12-h intervals (total of three injections). $5 \mathrm{~h}$ after beginning the diet and $3 \mathrm{~h}$ before killing the animals, mice in each group received one subcutaneous injection of the indicated amount of mevalonolactone. All mice were killed at 2 p.m., $7 \mathrm{~h}$ after the last dose of mevinolin. The livers from the three mice in each group were pooled for homogenization. Microsomes were treated with alkaline phosphatase and assayed for HMG CoA reductase activity as described under Methods. The " $100 \%$ of control values" for HMG CoA reductase activity were 470 and $142 \mathrm{pmol} / \mathrm{min}$ per $\mathrm{mg}$ microsomal protein for the control and cholesterol-fed animals, respectively.

biphasic response was observed when this experiment was repeated (data not shown). In the cholesterol-fed animals, the response was different in that HMG CoA reductase activity was suppressed by $>50 \%$ at mevalonolactone concentrations $<0.5 \mathrm{mg}$. Increases in the amount of mevalonate up to $10 \mathrm{mg}$ led to a slight further decrease in HMG CoA reductase activity.

Table II shows the effects of mevalonate on the relative amount of active and inactive HMG CoA reductase in the livers of control and cholesterol-fed mice treated with mevinolin. $2 \mathrm{~h}$ after mevalonate administration to mevinolin-treated mice on a control diet, the total HMG CoA reductase activity (i.e., that present after alkaline phosphatase treatment) had declined by $>85 \%$ (Table II). Mevalonate did not change the relative degree of stimulation by alkaline phosphatase in the fluoride-treated microsomes. Similarly, administration of mevalonate to mevinolintreated, cholesterol-fed rats led to a $75 \%$ decrease in total HMG CoA reductase, without a change in the proportion of enzyme in the active state as judged by alkaline phosphatase activation of the fluoride-treated microsomes. 
TABLE II

Mevalonate-mediated Suppression of HMG CoA Reductase Activity in Livers of Mice Fed Cholesterol and Treated with Mevinolin

\begin{tabular}{|c|c|c|c|c|c|}
\hline \multirow{2}{*}{\multicolumn{3}{|c|}{ Treatment of mice }} & \multirow{3}{*}{$\begin{array}{c}\text { Preparation } \\
\text { of } \\
\text { microsomes }\end{array}$} & \multicolumn{2}{|c|}{ HMG CoA reductase activity } \\
\hline & & & & -Alkaline & +Alkaline \\
\hline \multirow[t]{2}{*}{ Diet } & Mevinolin & Mevalonolactone & & phosphatase & phosphatase \\
\hline & & & & \multicolumn{2}{|c|}{ pmol/min/mg protein } \\
\hline \multirow[t]{2}{*}{ Control } & + & 0 & $+\mathrm{NaF}$ & 48 & 321 \\
\hline & & & $-\mathrm{NaF}$ & 308 & 367 \\
\hline \multirow[t]{2}{*}{ Control } & + & + & $+\mathrm{NaF}$ & 10 & 56 \\
\hline & & & $-\mathrm{NaF}$ & 36 & 45 \\
\hline \multirow[t]{2}{*}{$2 \%$ Cholesterol } & + & 0 & $+\mathrm{NaF}$ & 9.7 & 51 \\
\hline & & & $-\mathrm{NaF}$ & 38 & 46 \\
\hline \multirow[t]{2}{*}{$2 \%$ Cholesterol } & + & + & $+\mathrm{NaF}$ & 3.7 & 12 \\
\hline & & & $-\mathrm{NaF}$ & 11 & 16 \\
\hline
\end{tabular}

Six mice were fed either a control diet or a $2 \%$ cholesterol diet for $124 \mathrm{~h}$ as indicated. $96 \mathrm{~h}$ after beginning the diet, mice in both diet groups were injected subcutaneously with $1 \mathrm{mg}$ of mevinolin. The injections were repeated twice at 12-h intervals (total of three injections). $2 \mathrm{~h}$ after the last dose of mevinolin, groups of three control mice and three cholesterol-fed mice received one subcutaneous injection of $0.3 \mathrm{ml}$ of $10 \mathrm{mM}$ potassium phosphate ( $\mathrm{pH} \mathrm{4.5)}$ with or without $30 \mathrm{mg}$ of mevalonolactone. All mice were killed at 1 p.m., $2 \mathrm{~h}$ after injection of mevalonolactone or the control solution. The livers from the mice in each treatment group were pooled for homogenization and microsomes were prepared in the absence or presence of sodium fluoride as described in the legend to Table I. HMG CoA reductase was assayed after prior incubation in the absence or presence of $5 \mathrm{U}$ of alkaline phosphatase as described in the legend to Table I. Each value represents the average of two to four assays of microsomes prepared from pooled livers from three similarly treated animals.

\section{DISCUSSION}

The present data demonstrate that mevinolin, a competitive inhibitor of HMG CoA reductase (9), elicits an increase in the amount of HMG CoA reductase in the livers of mice. An increase in this enzyme occurred even when the animals had been fed cholesterol. The elevated level of HMG CoA reductase in the livers of the cholesterol-fed mice was rapidly suppressed when the animals were given small amounts of exogenous mevalonate in addition to cholesterol. Inasmuch as the livers of the cholesterol-fed mice already contained abundant cholesterol, it is unlikely that the mevalonate was exerting its suppressive effect by being converted to cholesterol. Rather, it seems likely that mevalonate itself, or a nonsterol product of mevalonate metabolism, may have been exerting a suppressive effect on the reductase (10).

These findings in the intact mouse are similar to previous findings in cultured human fibroblasts in which the combination of exogenous low density lipoprotein-cholesterol and exogenous mevalonate were more effective than low density lipoproteincholesterol alone in suppressing HMG CoA reductase in cells that had been grown in the presence of the
HMG CoA reductase inhibitor compactin $(5,10)$. The mevalonate effect cannot be reproduced with squalene, lanosterol, or hydroxylated sterols in fibroblasts (10). The fibroblast experiments have been interpreted to indicate the existence of a multivalent feedback mechanism in which cholesterol and a nonsterol product derived from mevalonate are both required for maximal suppression of HMG CoA reductase activity. By inhibiting the synthesis of mevalonate, compactin blocks the synthesis of both regulators and thus produces a compensatory increase in HMG CoA reductase that is reversed only when the cells can synthesize or take up sufficient amounts of both substances $(5,10)$. The current study demonstrates that a similar increase of HMG CoA reductase occurs in livers of cholesterol-fed mice given mevinolin. Although these results are compatible with the existence of a multivalent feedback mechanism in mouse liver, further studies will be necessary to deduce the details of the system and to identify the putative nonsterol feedback regulator.

The current in vivo experiments were designed primarily to measure changes in the total amount of HMG CoA reductase (active plus inactive forms) in mouse liver. To this end, we adopted a procedure previously 
established for rat liver (12) in which the microsomes were treated with $E$. coli alkaline phosphatase before assay to convert any phosphorylated inactive enzyme to the dephosphorylated active form. Neither mevinolin nor mevalonate affected the proportion of enzyme in the active form, as determined by alkaline phosphatase activation of microsomes prepared in the presence of sodium fluoride. Thus, the increase in total HMG CoA reductase elicited by mevinolin appears to represent an increase in the total number of HMG CoA reductase molecules. Such an increase might be produced theoretically by an enhanced rate of enzyme synthesis, a decreased rate of enzyme degradation, or both. Similarly, the suppression of the induced enzyme by mevalonate might be due either to inhibition of synthesis, to stimulation of degradation, or to both. Further experiments will be necessary to make this distinction.

If, as suggested by the current study, a multivalent feedback mechanism for HMG CoA reductase exists in liver, and if prevention of the mevinolin-mediated increase in HMG CoA reductase requires both cholesterol and a nonsterol product derived from mevalonate, the current findings may have relevance to the use of mevinolin and related compounds for the control of hypercholesterolemia in man. On the basis of the current data, we suggest that the rise in hepatic HMG CoA reductase observed after treatment with mevinolin and compactin may be prevented by the simultaneous administration of mevalonate or, preferably, the nonsterol substance derived from mevalonate that participates along with cholesterol in the suppression of HMG CoA reductase. Efforts to identify this putative nonsterol molecule are currently underway.

\section{ACKNOWLEDGMENT}

This work was supported by a grant HL-20948 from the National Heart, Lung, and Blood Institute, National Institutes of Health, Bethesda, Maryland.

\section{REFERENCES}

1. Endo, A., M. Kuroda, and K. Tanzawa. 1976. Competitive inhibition of 3-hydroxy-3-methylglutaryl coenzyme A reductase by ML-236A and ML-236B fungal metabolites, having hypocholesterolemic activity. FEBS (Fed. Eur. Biochem. Soc.) Lett. 72: 323-326.

2. Yamamoto, A., H. Sudo, and A. Endo. 1980. Therapeutic effects of ML-236B in primary hypercholesterolemia. Atherosclerosis. 35: 259-266.

3. Brown, A. G., T. C. Smale, T. J. King, R. Hasenkamp, and R. H. Thompson. 1976. Crystal and molecular structure of compactin, a new antifungal metabolite from Penicillium brevicompactum. J. Chem. Soc. Perkin Trans. I: $1165-1170$.

4. Kuroda, M., Y. Tsujita, K. Tanzawa, and A. Endo. 1979.
Hypolipidemic effects in monkeys of ML-236B, a competitive inhibitor of 3-hydroxy-3-methylglutaryl coenzyme A reductase. Lipids. 14: 585-589.

5. Brown, M. S., J. R. Faust, J. L. Goldstein, I. Kaneko, and A. Endo. 1978. Induction of 3-hydroxy-3-methylglutaryl coenzyme $A$ reductase activity in human fibroblasts incubated with compactin (ML-236B), a competitive inhibitor of the reductase. J. Biol. Chem. 253: 1121-1128.

6. Kaneko, I., Y. Hazama-Shimada, and A. Endo. 1978. Inhibitory effects on lipid metabolism in cultured cells of ML-236B, a potent inhibitor of 3-hydroxy-3-methylglutaryl-coenzyme-A reductase. Eur. J. Biochem. 87: 313-321.

7. Goldstein, J. L., J. A. S. Helgeson, and M. S. Brown. 1979. Inhibition of cholesterol synthesis with compactin renders growth of cultured cells dependent on the low density lipoprotein receptor. J. Biol. Chem. 254: 54035409.

8. Endo, A. 1979. Monacolin K, a new hypocholesterolemic agent produced by a Monascus species. J. Antibiot. (Tokyo). 32: 852-854.

9. Alberts, A. W., J. Chen, G. Kuron, V. Hunt, J. Huff, C. Hoffman, J. Rothrock, M. Lopez, H. Joshua, E. Harris, A. Patchett, R. Monaghan, S. Currie, E. Stapley, G. Albers-Schonberg, O. Hensens, J. Hirshfield, K. Hoogsteen, J. Liesch, and J. Springer. 1980. Mevinolin, a highly potent competitive inhibitor of HMG CoA reductase and cholesterol lowering agent. Proc. Natl. Acad. Sci. U. S. A. 77: 3957-3961.

10. Brown, M. S., and J. L. Goldstein. 1980. Multivalent feedback regulation of HMG CoA reductase, a control mechanism coordinating isoprenoid synthesis and cell growth. J. Lipid Res. 21: 505-517.

11. Endo, A., Y. Tsujita, M. Kuroda, and K. Tanzawa. 1979. Effects of ML-236B on cholesterol metabolism in mice and rats: lack of hypocholesterolemic activity in normal animals. Biochim. Biophys. Acta. 575: 266-276.

12. Brown, M. S., J. L. Goldstein, and J. M. Dietschy. 1979. Active and inactive forms of 3-hydroxy-3-methylglutaryl coenzyme A reductase in the liver of the rat.J. Biol. Chem. 254: 5144-5149.

13. Lowry, O. H., N. J. Rosebrough, A. L. Farr, and R. J. Randall. 1951. Protein measurement with the Folin phenol reagent. J. Biol. Chem. 193: 265-275.

14. Brown, M. S., J. R. Faust, and J. L. Goldstein. 1975. Role of the low density lipoprotein receptor in regulating the content of free and esterified cholesterol in human fibroblasts. J. Clin. Invest. 55: 783-793.

15. Nordstrom, J. L., V. W. Rodwell, and J. J. Mitschelen. 1977. Interconversion of active and inactive forms of rat liver hydroxymethylglutaryl-CoA reductase. J. Biol. Chem. 252: 8924-8934.

16. Beg, Z. H., J. A. Stonik, and H. B. Brewer, Jr. 1978. 3-Hydroxy-3-methylglutaryl coenzyme A reductase: regulation of enzymatic activity by phosphorylation and dephosphorylation. Proc. Natl. Acad. Sci. U. S. A. 75: 3678-3682.

17. Gibson, D. M., and T. S. Ingebritsen. 1978. Reversible modulation of liver hydroxymethylglutaryl CoA reductase. Life Sci. 23: 2649-2664.

18. Edwards, P. A., G. Popják, A. M. Fogelman, and J. Edmond. 1977. Control of 3-hydroxy-3-methylglutaryl coenzyme A reductase by endogenously synthesized sterols in vitro and in vivo. J. Biol. Chem.252: 10571063. 